\title{
Public service og politisk balance: En typologi
}

\section{AF DAVID NICOLAS HOPMAN}

Selv om der i offentligheden ofte diskuteres, hvorvidt danske tvnyheder er politisk farvede, er vores faktiske viden om spørgsmålet beskeden. I modsætning til vores nabolande har vi i Danmark ingen tradition for regelmæssige, empiriske indholdsanalyser af tv-nyheder. Med afsæt i forskningen fra andre europæiske lande diskuterer denne artikel derfor, hvordan politisk balance og bias kan undersøges i en dansk sammenhæng. Centralt for diskussionen er, at det ikke er tilstrækkelig alene at analysere de sendte tv-nyheder, men at journalisternes arbejdsbetingelser også skal inddrages i analysen. Ud fra disse to aspekter udledes en ny typologi, der i modsætning til tidligere typologier ikke kun dækker forskellige former for politisk bias i medierne, men også forskellige former for politisk balance.

„Det er dybt mærkværdigt, at de vil brænde fem millioner kroner af på det [forskning i 'public service'-medier]. Jeg håber blot, at de vil se på kvaliteten frem for på mængden. Det nytter ikke at sidde og tælle, hvor mange nyhedsindslag politikere fra et bestemt parti er med i, for det er fuldstændig afhængigt af den aktuelle dagsorden.“

Michael Dyrby, TV2 Danmarks nyhedschef i Politiken, 22.06.05, 1. sek., side 2 


\section{Public service og politisk balance: en typologi}

Bølgerne gik højt, da Danmarks Radios nyhedsdirektør Lisbeth Knudsen sagde sit arbejde op i november 2006. Flere kommentatorer mere end antydede i den offentlige debat, at Lisbeth Knudsen var blevet gået, fordi hun angiveligt var for venstreorienteret. Hvis nogen var i tvivl om, hvor noget af presset kom fra, offentliggjorde den tidligere generaldirektør for DR, Christian Nissen, i begyndelsen af 2007 en erindringsbog, som blandt andet indeholdt en mere eller mindre direkte e-mail fra den dav. konservative kulturminister Brian Mikkelsen - han var utilfreds med DR's dækning af Irakkrigen.

Den danske radio- og tv-lov forpligter Danmarks Radio til følgende: „Ved informationsformidlingen skal der lægges vægt på saglighed og upartiskhed“ (§ 10). En diskussion om, hvorvidt Danmarks Radio overholder dette, er ikke ny. I 2002 grundlagde et kendt medlem af Dansk Folkeparti foreningen „Kritiske Licensbetalere“, „hvis mål er at observere venstreorienteret propaganda fra DR's side“ (www.danskfolkeparti.dk, 21.05.07). Foreningen blev nedlagt efter to år i modsætning til den af Erhard Jakobsen stiftede forening „Aktiv Lytterkomité“ (senere „Aktive Lyttere og Seere“) (Hjarvard 1997: 155f.). Den blev oprettet i 1972 og bestod i alt i 20 år med op til 50.000 medlemmer. Foreningen anklagede ofte Danmarks Radio for ensidig, propagandistisk venstreorienteret dækning. I foreningens medlemsblad beskrev Erhard Jakobsen under overskriften „Meningsterroren i Danmarks Radio må standses!“ dele af DR’s programflade som venstreorienteret „forkyndelse“ (Jakobsen 1977: 5).

Det er selvfølgelig vanskeligt at bedømme, hvilken effekt denne kritik havde og har på Danmarks Radio. Stig Hjarvard konkluderer, at Erhard Jakobsens forening bidrog „i høj grad til et ideologisk klima, som gjorde det vanskeligt at bruge mediet aktivt, eksperimenterende og kritisk at bearbejde de kulturelle og sociale brydninger" (Hjarvard 1997: 156; sml. Hjarvard 2006).

I modsætning til Sverige, hvor forskere som Jörgen Westerståhl og Kent Asp over en årrække har gennemført systematiske indholdsanalyser af svensk fjernsyns dækning af enkelte hændelser eller valgkampe, er systematisk viden om danske „public 
service“-stationers politiske nyhedsdækning begrænset. Derfor gennemføres der for tiden et forskningsprojekt på Syddansk Universitet, hvis mål er at indholdsanalysere tv-mediernes dækning af valgkampe i Danmark gennem de seneste 15 år.

\section{En ny typologi nødvendig}

Uanset de konkrete data, indholdsanalyser af tv-nyheder frembringer, er det vigtigt at gøre sig klart, hvordan disse data skal analyseres, og hvad der skal til for at kunne konkludere, at et mediums nyhedsdækning er venstre- eller højreorienteret. McQuail (1992: 191) beskriver med rette bias som et "slippery" koncept. Han foreslår en typologi over politisk bias (men ikke politisk balance) på baggrund af tidligere forskning, men den hjælper os kun et begrænset stykke hen ad vejen: Således konkluderer Semetko (2003: 521), at McQuails definitioner "help us to think about the parameters of bias, [nevertheless] they primarily point out the difficulty in operationalizing the concept".

Som indledningen påpeger, er det selvfølgelig oplagt at se på den faktisk sendte nyhedsdækning. Artiklens indledning peger dog også på spørgsmål om politisk pression og lovgivningsmæssige rammer for journalisternes arbejde, som skal inddrages i en systematisk analyse af de indsamlede data. Fordi der ikke findes relevante danske empiriske undersøgelser, vil jeg i det følgende sammenligne undersøgelser fra andre landes „public service“medier. Denne artikel præsenterer og systematiserer væsentlige overvejelser, som er del af en analyse af politisk balance i medierne.

I flere andre lande har forskere i mange år gennemført empiriske analyser af tv-mediernes dækning af valgkampe. Disse analyser peger på, at der skal ses på især to dimensioner, når politisk balance og bias i tv-nyheder skal analyseres: For det første journalisternes produktionsbetingelser, for det andet indholdet af dækningen. Det er med andre ord ikke tilstrækkeligt kun at se på indholdet, som ellers gjort i mange undersøgelser. Indholdsanalyse som redskab er "limited in its ability to isolate and identify bias”, da der kan være mange årsager til skæv dækning af politikere (Patterson \& Donsbach 1996: 460). 
Hofstetter $(1976,1978)$ tager i sin typologi over politisk bias netop hensyn til begge dele: Det journalistiske produkt og journalisternes produktionsbetingelser. I sin standardsættende analyse af den US-amerikanske præsidentvalgkamp i 1972 skelner han mellem strukturel og situationel bias på den ene side og politisk bias på den anden side. Årsagerne bag strukturel bias kan være, at f.eks. tv som medium kræver andet materiale end radio, mens situationel bias i valgkampsdækning kan skyldes forskellig aktivitetsniveauer hos kandidaterne. Politisk bias derimod "involves selection of news based on political considerations or prejudice” (Hofstetter 1976: 188). Det vil sige, der også ses på, på hvilken baggrund nyhedsindslagene bliver valgt. Med andre ord: Et er at måle mediernes dækning på en række indikatorer, noget andet er at forklare årsagen bag den dækning, der vises på tv som det også fremgår af artiklens indledende citat fra TV2's nyhedschef Michael Dyrby. Derimod omfatter Hofstetters typologi ikke politisk balance i medierne.

I figur 1 vises en ny typologi over politisk balance og bias i medierne, hvis udgangspunkt er de to dimensioner ,journalistisk produkt“ og ,journalisternes produktionsbetingelser“. For det første er det et spørgsmål, om det journalistiske produkt favoriserer bestemte politiske aktører. For det andet er det et spørgsmål om, hvorvidt journalister arbejder ud fra professionelle kriterier for nyhedsjournalistik. I praksis vil det sige, at historiernes nyhedsværdi og relevans er afgørende for, om de bringes i nyhederne, men ikke om historierne omhandler politikere fra parti A eller parti B (sml. Semetko 1996: 51). Med Shoemaker \& Reeses (1996) ord er det et spørgsmål om, hvorvidt medierutiner er under pres udefra.

For at gøre den senere diskussion mere overskuelig, inddeles figuren i fire felter, som indfanger de afgørende kombinationer af to dimensioner. Dækningen af valgkampe, som er nogenlunde politisk balanceret og professionelt lavet, beskrives som „professionelt balanceret“. Er den derimod ikke konsekvent professionelt lavet, dvs. det er ikke altid historiernes nyhedsværdi, som er afgørende for, om de bringes i nyhederne, beskrives dækningen som „konstrueret balance“. Dækning, som er mindre professionel og samtidigt politisk ubalanceret, beskrives som 
„politisk ubalanceret“. Den sidste kategori, „professionelt ubalanceret“, dækker over ubalanceret dækning, men som er blevet produceret konsekvent professionelt. I modsætning til McQuails typologi eller Hofstetters typer af bias inkluderer den her præsenterede fremgangsmåde derved definitioner på både bias og balance.

For at gøre det mere konkret, hvad der menes med disse fire felter i figur 1, diskuteres i det følgende eksempler fra fire forskellige lande: Storbritannien, Spanien, Sverige og Tyskland. Kun få studier af politisk balance i tv-nyheder sammenligner udførligt forskellige lande (f.eks. Schoenbach, de Ridder \& Lauf 2001; Semetko 1996, 1996a). Det kan ikke i sig selv undre givet de store forskelle mellem journalistik fra et land til et andet land - men i den komparative tilgang ligger også muligheden for at identificere afgørende karakteristika af et lands journalistik (Esser 2002). Når det er præcis disse fire lande, jeg ser nærmere på, skyldes det for det første, at deres „public service“-mediers politiske journalistik er velbeskreven i den tilgængelige litteratur. For det andet har alle fire lande det tilfælles, at deres statsoverhoveder ikke er relativt indflydelsesrige præsidenter som f.eks. i Frankrig, hvor reguleringen af politisk balance på tv selvfølgelig er influeret af, hvilket politiske system landet har (se note 1). Det gør en direkte sammenligning mellem landene mere oplagt. For det tredje står de fire lande hver for sig for en bestemt type af nyhedsdækning

\section{Figur 1}

En typologi over to centrale dimensioner $\mathrm{i}$ analysen af politisk balance på „public service" -tv.

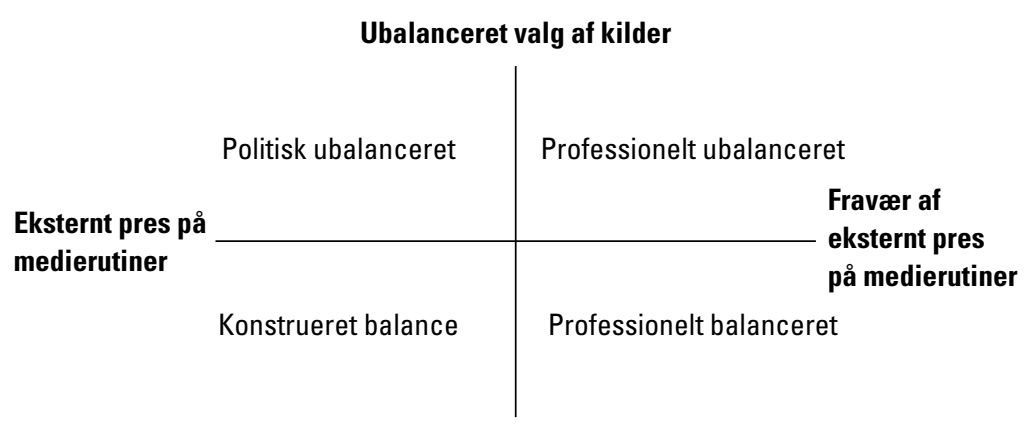

Balanceret valg af kilder 
(sml. Hopmann 2009). Desuden vil det blive diskuteret, hvorfor det er særligt oplagt at analysere „public service“ i denne sammenhæng.

\section{Journalisternes produktionsbetingelser}

I et første skridt ses der nærmere på, under hvilke betingelser journalister på „public service“-kanaler i de fire nævnte lande dækker valgkampe. Spørgsmålet er, hvorvidt journalisterne har mulighed for at arbejde overvejende professionelt på baggrund af journalistiske normer, eller om de er nødt til at tage hensyn til udefrakommende regler og politisk indblanding, som tvinger dem til at afvige fra professionelle journalistiske normer for nyhedsproduktion. Storbritanniens BBC og Spaniens TVE1 er eksempler på to „public service“-medier, hvor journalister skal tage hensyn, der ofte tvinger dem til at afvige fra professionelle normer. Derimod har journalister på tyske ARD \& ZDF og svenske SVT en mere autonom stilling.

\section{Storbritannien \& Spanien: snævre rammer for dækningen}

Ved siden af Frankrig er Storbritannien et af de europæiske lande med de mest detaljerede krav til tv-stationernes dækning af valgkampe. ${ }^{1}$ Over tid har der i Storbritannien etableret sig en tradition for, at omfanget af de såkaldte "party election broadcasts" eller "PEB's" anvendes som målestok for, hvor stor en andel de forskellige partier skal have af BBC's dækning af valgkampe (Scammel \& Semetko 1995; Semetko 1991, 1996; Semetko \& Schoenbach 1994: 6o). PEB's er præsentations- eller reklamefilm, partierne selv står for. Hvor mange hvert parti må sende, afgøres af tv-stationerne og partierne i et lukket gremium. Typisk er et forhold på „5:5:4“ til hhv. Labour, Konservative og Liberale. Baggrunden for omfanget er blandt andet partiernes tilslutning ved det sidste valg og bivalg, antal opstillede kandidater m.m. (Gunter 1997: 141; Scammel \& Semetko 1995: 23).

På BBC tjekkes ikke kun partiernes andele af sendetid, men der måles også på en lang række andre indikatorer. I en observationsstudie fra 1992 af BBC's nyhedsredaktion (Blumler, Gurevitch \& Nossiter 1995: 75f.) nævnes følgende punkter: 
"The amount of time given in bulletins to recorded extracts of politicians' campaign statements (though not necessarily so closely stopwatched as in previous elections);

Place in the running order, especially frequency of leading the bulletin;

Balancing occasions when much more time is given to one party leader than another;

Week-by week scheduling of leader interviews in programmes;

Reporting of second-string politician speeches;

Live reporting from press conferences;

'Equivalence of tone' in leader trail reports;

Similarity of placement of favourable opinion poll results in the bulletin [...];

Coverage of particularly newsworthy constituency candidates;

Complementarity in the framing by specialist correspondents of concluding assessments on some contested issue“. (Se også Gurevitch \& Blumler 1993: 429).

Som vi vil se i næste afsnit, giver nogle af de ansatte på BBC udtryk for, at disse mange krav til politisk balanceret dækning sætter snævre grænser for deres produkt, som ofte er i konflikt med professionelle kriterier for nyhedsproduktion - især kriterier for nyhedsværdi og relevans.

Både BBC og ITV har i 199o'erne annonceret at ville følge reglerne for politisk balance mindre snævert i fremtiden. Indtil videre tyder data over deres dækning dog på, at deres tilgang til valgkampe ikke har forandret sig meget (Harrison 2002; Scammel \& Semetko 1995; Semetko 1996, 2003). BBC tager påbuddet om politisk balancerede indslag så seriøst, at det ikke kun gælder nyheder. Blot et eksempel: Da popgruppen Pet Shop Boys i april 2006 skulle præsentere sangen "I'm with stupid", der handler om kærlighed mellem en klog og en mindre klog person, skulle danserne på scenen have masker af Tony Blair og George W. Bush på. BBC insisterede på, at maskerne skulle være politisk ,afbalancerede“, hvilket i dette tilfælde betød, at danserne også måtte have masker af de Konservatives og Liberales ledere samt Jacques Chi- 
rac og Vladimir Putin på (www.petshopboys.co.uk, 30.01.07).

Selv om reglerne for spansk „public service“-fjernsyn i udgangspunktet minder meget om BBC's, er TVE1 på mange punkter endnu langt væk fra BBC (Semetko \& Canel 1997). Indtil for nylig blev TVE1 stærkt politisk styret: Den øverste chef blev bestemt af regeringen og vedkommende udpegede så blandt andet cheferne for nyhederne (Díez-Nicolás \& Semetko 1999; Semetko \& Canel 1997). Således udskiftede socialisterne efter deres valgsejr i 1982 også hele ledelsen af tv-kanalen (Díez-Nicolás \& Semetko 1997). ${ }^{2}$

I modsætning til de fleste andre „public service“-stationer bliver TVE1 ikke betalt af en husstandslicens, men af det offentlige, hvilket i praksis vil sige regeringen. Samtidigt oparbejder TVE1 et stort underskud, som regeringen så betaler. Fra TVEl's side lægges ikke skjul på, at netop regeringen forstås som ejer, da den jo også udpeger ledelsen (Semetko \& Canel 1997). Díez-Nicolás \& Semetko (1997) beskriver TVE1's dækning af valgkampen i 1996, som om den først og fremmest blev produceret til politikerne og i mindre grad til det brede publikum, hvilket nogle journalister på TVE1 synes at være klar over (sml. Semetko \& Canel 1997: 469).

I princippet skal TVE1's dækning af valgkampe være "equitativo y correcto”, dvs. „upartisk og korrekt“ (Díez-Nicolás \& Semetko 1999: 179), og omfanget af den dækning, de enkelte partier får, aftales på forhånd og svarer til partiernes tilslutning ved det forudgående valg (Semetko \& Canel 1997: 465). Men praksis er ofte langt fra disse krav. Dette skyldes blandt andet, at kravene kun anvendes på dækningen af valgkampen, som officielt kun varer to uger. Desuden bliver "normale nyheder" ikke talt med, hvilket giver bred mulighed for at promovere tv-stationens ejer (Díez-Nicolás \& Semetko 1997: 10). Samtidigt forholder TVE1 sig så passivt, når de skal fylde valgkampsblokken i deres nyheder, at det nogle gange ender med, at tv-stationen spørger partierne, hvad de ønsker at få sendt (Semetko \& Canel 1997: 468). Journalister på TVE1 er også stærkt selvkritiske og lægger ikke skjul på, at deres dækning af valgkampe ikke altid er professionel journalistik (Semetko \& Canel 1997). 


\section{Tyskland \& Sverige: autonome journalister}

De to store tyske „public service“-kanaler ARD og ZDF er ligeledes eksempler på en tæt politisk styring. Men denne politiske styring adskiller sig fra spanske TVE1 ved ikke at være ensidig (Díez-Nicolás \& Semetko 1997; Semetko \& Canel 1997). I Tyskland er det kutyme at ansætte ledende personer efter partibog, således at begge de to store fløje i tysk politik (i praksis vil det sige SPD vs. CDU/CSU) tilgodeses og udligner hinanden (Schoenbach 1991: 72f.; Semetko \& Canel 1997: 476). Journalister på ARD og ZDF er dog ikke underlagt snævre regler for eller krav til deres dækning af valgkampe, som det kendes fra britisk eller spansk fjernsyn, men kun generelle principper om saglighed og alsidighed.

Det samme gælder produktionsbetingelserne på svensk SVT, hvor der gælder lignende genereller principper som i Tyskland: SVT skal producere „opartisk och sakligt samt med beaktande av att en vidsträckt yttrandefrihet och informationsfrihet skall råda i televisionen" ( $\$ 6$ i sendetilladelsen for SVT; sml. Asp 1983: 336). Hvordan SVT lever op til dette, er op til stationen at afgøre (Petersson, Djerf-Pierre, Holmberg, Strömbäck \& Weibull 2006: 52).

Samlet set findes der hverken i Tyskland eller Sverige skrevne eller uskrevne snævre regler for upartiskhed, der minder om de mere detaljerede regler i Spanien eller Storbritannien, for slet ikke at tale om den politiske indblanding, vi hidtil har set i Spanien.

\section{Journalisternes produkt: politisk balanceret eller biased}

Lad os i et næste skridt se på tv-stationernes konkrete dækning, den anden dimension i figur 1: Hvordan dækkes valgkampe i de fire lande? Spanske og tyske „public service“-medier er eksempler på to tv-stationer, der ofte dækker valgkampe politisk ubalanceret til gunst for regeringen. Derimod er dækningen på BBC i Storbritannien og SVT i Sverige nogenlunde balanceret mellem de forskellige politiske aktører. Samtidigt skal der ses på, hvordan disse resultater skal tolkes, når de sammenholdes med diskussionen om produktionsbetingelserne i de fire lande. 


\section{Spanien og Tyskland: favorisering af regeringen}

Som det kan forventes ud fra beskrivelsen af de betingelser, spanske journalister på TVE1 skal producere under, er deres produkt politisk ubalanceret. Undersøgelser af valgene i 1993, 1996, 2000 og 2004 har vist, at den aktuelt siddende regering begunstiges af TVE1. ${ }^{3}$ Journalisterne på TVE1 ville i Semetko \& Canels undersøgelse (1997) ikke indrømme, at de i nogle tilfælde bevidst sendte mere materiale om regeringen for at promovere den. Men som nævnt før er journalisterne udmærket godt klar over, at de „ejes“ af regeringen, og at deres ledelse bliver udpeget af regeringen.

Desuden bekræftes formodningen om, at den spanske tv-stations bias skyldes et særligt hensyntagen til politiske interesser og ikke er et resultat af journalistisk professionelle kriterier, af to andre indikatorer: For det første viser en analyse af evalueringer af partierne ytret ved journalister, at det daværende regeringsparti PSOE er blevet evalueret væsentlig mere positivt (eller mindre negativt) end oppositionspartiet PP, især i 1993, i mindre grad i 1996 (Díez-Nicolás \& Semetko 1999: 188). For det andet har den private konkurrent til TVE1, Antena 3, en langt mere politisk balanceret dækning af valgkampen (Díez-Nicolas \& Semetko 1997). Skal de produktionsbetingelser, journalisterne på TVE1 har, og den faktisk sendte dækning af spanske valgkampe sammenfattes, kunne det gøres med overskriften „politisk ubalanceret“ jf. figur 1 .

Tysklands ARD \& ZDF adskiller sig fra Spaniens TVE1 ved, at der ikke findes præcise regler for, hvordan det politiske skal dækkes (Schoenbach 1991; Semetko 1996). Desuden findes der ingen ensidig politisk indblanding i journalisternes arbejde. Tyskland adskiller sig også fra flere andre lande ved, at medierne generelt ikke sætter meget fokus på valgkampe (Esser \& D’Angelo 2006: 52; Schönbach \& Semetko 1995; Semetko 1996; Weiß 1982). Nyhedsudsendelser på tysk tv, både på private og „public service“kanaler, bliver typisk ikke forlænget, og ingen særlige valgblokke haves, som det kendes fra mange andre lande som f.eks. Spanien og Storbritannien. Tværtimod er valgkampe for journalister på tv-stationerne "business as usual", og de holder fast i de normale kriterier for nyhedsværdi af enkelte historier. Selve valgkampen 
bliver af nogle tyske journalister beskrevet som "propaganda“ uden større nyhedsværdi i sig selv (Schneider, Schönbach \& Semetko 1999; Semetko 1996).

Konsekvensen af den tyske fremgangsmåde er, at regeringen ofte får en markant ,amtsbonus“ eller „Kanzlerbonus“ i henhold til synlighed på tv-skærmene. ${ }^{4}$ Selv om det er valgkamptider, er regeringen jo fortsat $\mathrm{i}$ embedet og foretager sig heraf følgende handlinger, som ofte er mere nyhedsværdige, end hvad oppositionen kan finde på. Regeringens politik er officiel, mens oppositionen kun kan komme med forslag, som har begrænsede chancer for at blive gennemført. Flere resultater peger på, at der ikke er tale om en slagside grundet partipolitiske holdninger fra tvstationenes side: For det første er forskellene mellem de forskellige tyske tv-stationer, „public service“ eller private, ikke særlig store - tyske journalister synes at handle nogenlunde ens. Tyske journalister har med andre ord generelt en forholdsvis snæver forståelse af, hvad der er relevant (Schoenbach, de Ridder \& Lauf 2001). For det andet er indslag med direkte reference til det pågående valg typisk politisk balanceret. Desuden ses der typisk ingen eller næsten ingen bonus i henhold til f.eks. evalueringer eller tonen i indslagene. Endeligt indikerer indholdsdataene over årene, at bonussen synes at svinge i takt med, hvor gode chancer oppositionen har. Det vil sige, hvis det ser ud, som om oppositionen måske vil vinde valget - og derfor journalistisk set er mere nyhedsværdig - er „amtsbonussen“ mindre. Schönbach \& Semetko (1995: 56) beskriver den til forbundsdagsvalget 1994 fundne „amtsbonus“ derfor som en „Aktionsbonus“, der er en „weitgehend 'ideologiefreier', eben professioneller Bonus“ (sml. Schönbach \& Semetko 1996). Schönbach \& Semetko (2000) konkluderer, at tyske journalister er "gnadenlos professionell“.

Tyskland har med andre ord det tilfælles med Spanien, at „public service“-mediernes dækning af valgkampe ikke er politisk balanceret, men baggrunden herfor er, som diskussionen af journalisternes produktionsbetingelser har anskueliggjort, en anden: I Tyskland forstås valgkampe ud fra en professionel tilgang til nyhedsproduktionen som ikke særlig nyhedsværdige i sig selv. Derved adskiller tyske journalister sig fra spanske og britiske ved at holde fast i deres professionelle kriterier for nyheder. Sammen- 
fattende kan dækningen i Tyskland derfor karakteriseres som „professionelt ubalanceret“.

\section{Storbritannien \& Sverige: balance i dækningen}

I Storbritannien har dækningen af valgkampe gennem de seneste mange år være nogenlunde balanceret. Selvfølgelig har balancen ikke altid været perfekt i forhold til de ovenfor beskrevne britiske balancekrav, men nogenlunde i hvert fald hvad angår den sendetid, de enkelte partier får. De Konservative og Labour får typisk den sammen andel dækning samt de Liberale den aftalte mindre andel (Norris, Curtice, Sanders, Scammel \& Semetko 1999; Harrison 2002). Til nogle valg ses en begrænset bonus til den aktuelt siddende regering, men den er ikke særligt udpræget (se f.eks. Harrison 1997 om valgene i 1992 og 1997). BBC lever således mere eller mindre op til de krav, som stilles til dens dækning af valgkampe.

Derimod lever BBC's dækning ligeså lidt som den spanske altid op til journalistisk professionelle kriterier for nyhedsproduktion. Konsekvensen af briternes fremgangsmåde er til tider kedelige indslag om oppositionen blot for at balancere mediedækningen: „[In Großbritannien] unternehmen die Medien ... in den letzten Wochen vor dem Wahltag - oft auf uns geradezu lächerlich wirkende - Anstrengungen, auch aus den scheinbaren Propagandaaktivitäten der Opposition und ihrer Politiker Nachrichten zu machen“ (Schönbach \& Semetko 1994: 338). I en sammenligning med Tyskland skriver Schneider, Schönbach \& Semetko (1999: 269), at denne „latterlige“ fokus på balance i britiske nyheder frembringer ,in deutschen Augen zuweilen skurrile Blüten wenn etwa dem Staatsbesuch des Amtsinhabers mit gleicher Ausführlichkeit die Bäderreise des Herausforderers gegenübergestellt wird“.

„Public service“-stationernes dækning af valgkampe i Spanien og Storbritannien har sammenfattende det tilfælles, at de til tider er uprofessionelle set ud fra journalistiske kriterier for nyhedsproduktion. På den anden side adskiller de sig fra hinanden ved, at $\mathrm{BBC}$ stort set lever op til gængse krav om balance mellem de forskellige politiske grupperinger, hvilket TVE1 ikke gør. BBC’s dækning kan derfor sammenfattes som „konstrueret balance“. 
Sverige har tilfælles med Storbritannien og Tyskland, at der over årene ikke ses nogen systematisk begunstigelse af bestemte politiske partier til den ene eller anden side (Asp 1983, 2006). Asp (2006) konkluderer, at dette kan skyldes et bevidst ønske hos medierne om at balancere deres dækning. Men den afgørende forklaring for svenske mediers balance er ifølge Asp journalisternes professionelle tilgang til stoffet: Befolkningens tilslutning til partierne forstås som en indikator for de enkelte partiers relevans og dermed deres nyhedsværdi.

„Ett visst mått balanstänkande förekommer med största sannolikhet i valrörelsebevakningen, men grundläggande nyhetsvärderingsprinciper väger troligen tyngre. Ett partis exponering i nyhetsmedierna är i första hand en funktion av journalisternas bedömningar av ett partis politiska vikt och ett partis publika intresse. Och det är en urvalsprincip som i stort sett gällt $i$ alla de nio riksdagsval som undersökts“ (Asp 2006: 37; sml. Asp 1983, 1988, 2003).

I lighed med tyske medier er der heller ikke store forskelle mellem de forskellige mediers dækning af valgkampe i nyhedsudsendelser. Samlet set kan svensk ,public service“-fjernsyn derfor beskrives som „professionelt balanceret“. Journalister på SVT er ikke underlagt snævre regler for politisk balance eller politisk indblanding, samtidigt er deres dækning stort set balanceret mellem de forskellige politiske aktører i Sverige.

\section{Diskussion}

Interessen for mediernes politiske balance er ikke ny (Smith 1981). Det gælder især „public service“-medierne, fordi disse medier er offentligt betalte, enten ved skattepenge eller husstandslicenser. Samtidigt har „public service“-medier længe haft monopol på radio- eller fjernsynskanaler i deres respektive lande. Derfor kræver mange deltagere i debatten, at disse medier dækker hele befolkningen og ikke kun bestemte spektre, som mange dagblade gør (cf. Starkey 2007). Det lægger betegnelserne "public service broadcasting” eller „öffentlich-rechtlicher Rundfunk“ jo 
allerede op til, og diskussionen om politisk balance og bias skal ses i denne sammenhæng: “'Balance' in broadcasting is a strange concept, with no equivalent for the press. ... 'Balance' is the child of 'public service'” (Seaton \& Pimlott 1983: 133).

I denne artikel blev dækningen af valgkampe på „public service“-fjernsyn i forskellige lande præsenteret. Gennemgangen fremhæver to dimensioner, som er centrale i en analyse af politisk balance i medierne. For det første er det selvfølgelig spørgsmålet, hvilket produkt journalisterne producerer. I Tyskland og Spanien er „public service“-stationernes dækning af valgkampe ofte politisk ubalanceret til fordel for regeringen. Derimod er dækningen i Storbritannien og Sverige nogenlunde politisk balanceret. Men for det andet er det ligeså vigtigt at se på, hvilke grænser der er for journalistisk professionalisme. I Storbritannien er der detaljerede krav til politisk balance, i Spanien findes desuden en stærk politisk indblanding i journalisternes arbejde. I Tyskland og Sverige derimod findes sådanne snævre grænser ikke. Figur 2 viser placeringen af disse fire lande i forhold til de to skitserede dimensioner.

\section{Figur 2}

En oversigt over placeringen af "public service“-medier i Spanien, Storbritannien, Sverige og Tyskland i forhold til centrale dimensioner i analysen af politisk balance.

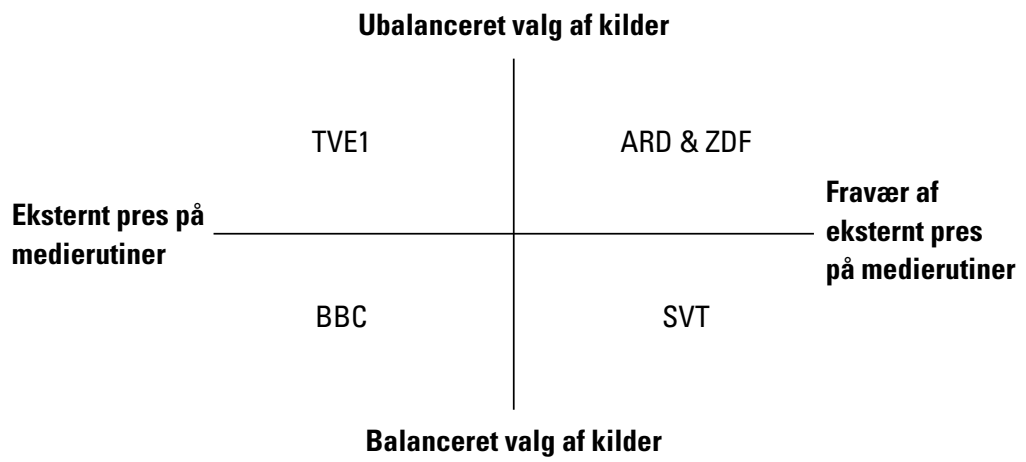

Gennemgangen af disse fire lande peger på, at det ikke er nok blot at se på „public service“-stationernes journalistiske output, hvilket TV2 Danmarks nyhedschef Michael Dyrby i artiklens ind- 
ledende citat også har givet udtryk for. Output skal ses i lyset af inputbetingelserne ved at analysere det ud fra de produktionsbetingelser, journalister arbejder under. Samtidigt påpeger gennemgangen også, at en sammenligning af flere forskellige lande kan være en gevinst for medieanalyser.

I konkrete analyser af indholdsanalyser af mediernes dækning af det politiske skal der selvfølgelig ses nærmere på de to i denne artikel beskrevne dimensioner. For det første rejser gennemgangen i denne artikel spørgsmålet, hvordan det kan være, at både svenske og tyske journalister arbejder efter professionelle normer, men at dækningen er politisk balanceret i det ene land, men ikke i det andet land. Schoenbach, de Ridder \& Lauf (2001) analyserer dækningen af valgkampe i Tyskland og Nederlandene, og undersøgelsen peger på faktorer, der muligvis også kan forklare, hvorfor professionel journalistik i Sverige resulterer i nogenlunde politisk balanceret dækning i modsætning til Tyskland. Grundet forskelle i de politiske systemer er den nyhedsværdi, som er knyttet til forskellige politiske poster, mere jævnt fordelt $\mathrm{i}$ Nederlandene end i nabolandet. Tyskland har - sammenlignet med Nederlandene (eller Sverige) - relativt entydige magtforhold, stærke regeringsledere og mindre autonome ministre. Det kan medføre mere ulige fordelte nyhedsværdier blandt de forskellige politiske aktører - og derfor mindre politisk balance i medierne.

For det andet er det vigtigt at diskutere mere detaljeret, hvordan politisk balance og bias i medierne defineres, når specifikke indikatorer som omfang af politikernes optræden på tv eller tonen i indslag skal evalueres. Typisk defineres medieindhold som politisk balanceret, hvis omfanget af medieomtale svarer til partiernes størrelse eller de to politiske hovedblokke i forhold til hinanden. I Storbritannien er udgangspunktet som nævnt den aftalte fordeling af PEB's. Men i litteraturen på området findes ingen bredt accepteret operationaliserbar målestok for politisk balance i medierne. McQuail (1992) og Shoemaker \& Reese (1996) gør i deres omfattende diskussioner af bias, objektivitet og politisk balance i medierne opmærksom på, at enhver målestok altid vil være relativ og diskutabel. Konklusioner om politisk bias eller balance vil altid findes ud fra en bestemt, men selvvalgt definition. 
Derfor er det vigtigt at holde sig begrænsningerne i de valgte fremgangsmåder for definitionen af politisk balance og bias for øje: Hvis medieomtalen er balanceret efter f.eks. partiernes stemmeandel ved sidste valg, kan denne balancering faktisk betyde en skæv omtale af valgkampen, hvis et af partierne ikke fører en særlig aktiv valgkamp. Virkeligheden, hvordan end defineret, behøver selvsagt ikke være politisk balanceret (se bl.a. Hofstetter 1976, 1978; Kuklinski \& Sigelman 1992; Schiffer 2006). Patterson \& Donsbach (1996: 460) fremhæver i forlængelse heraf: “The press's watchdog role also confounds content-analytic judgments about bias; almost no politician or party escapes criticism when personal or policy failings are at issue". Derfor kolliderer balancekrav til journalistikken også ofte med journalistikkens professionelle normer for nyhedsdækning. Entman (1989: 34) fremhæver tilsvarende, at "ironically, strict balance violates its own purpose: to ensure that the news offers a neutral, factual mirror of reality".

Spørgsmålet er så, hvad denne diskussion betyder for analyser af dansk „public service“: Danmark minder umiddelbart mest om Sverige og Tyskland, idet der her ikke findes snævre grænser for valgkampdækning (Kamil 2007: 112; Lund 1975). Dog minder det danske politiske system mere om det svenske end det tyske, hvilket kan betyde en mindre skæv fordeling af politikernes nyhedsværdi. Derfor kan mindre politisk ubalance end i Tyskland forventes i Danmark. Hvorvidt det er tilfældet, vil det føromtalte forskningsprojekt på Syddansk Universitet være med til at belyse nærmere.

Indtil videre er empirisk viden om partiskhed på dansk „public service“-tv begrænset. En af de få danske empiriske analyser har peget på, at Danmarks Radios dækning af Irakkrigen ikke var forskellig fra andre mediers dækning, men at danske medier generelt var fælles om ikke at være særlig kritiske over for den danske og den amerikanske regerings planer om at gå i krig (Hjarvard, Kristensen \& Ørsten 2004). En senere analyse af valgkampen i 2005 viser, at medierne især fokuserede på Anders Fogh Rasmussen og Mogens Lykketoft samt deres respektive partier (Bro, Jønsson, Jørgensen \& Pedersen 2005). Undersøgelsens resultater peger på, at der måske var tale om en „regeringsbonus“ i 
de danske mediers dækning af valgkampen i 2005, men dataene er ikke særlig detaljerede.

Heller ikke anekdoter peger i en bestemt retning: Efter at DR's tidligere nyhedschef Lisbeth Knudsen var blevet gået, fordi hun angiveligt var for venstreorienteret, blev hun chefredaktør på Berlingske Tidende - et dagblad med en borgerlig profil.

\section{N OTER}

1. Se CSA (2000). Siden slutningen af 1980'erne overvåger myndigheden "Conseil supérieur de l'audiovisuel" (CSA) franske tv-stationers dækning af valgkampe (Gerstlé 1991; Hill 2004; Kuhn 2004). Op til især præsidentvalgkampe er der præcise regler for den relative andel af dækningen, de enkelte kandidater må få. Til parlamentsvalg kræves som udgangspunkt, at en tredjedel af dækningen gives til hhv. regeringen, parlamentets flertal og dets opposition. Data viser, at stationerne generelt overholder kravet til tredelingen (CSA 2000, 2006), om end CSA's muligheder for at sanktionere overtrædelser af disse regler åbenbart er ret begrænset (Gerstlé 1991). Italien har en lignende snæver regulering på området (se CSA 200o; Petersson, DjerfPierre, Holmberg, Strömbäck \&Weibull 2006).

2. Sidenhen er reglerne blevet ændret således, at parlamentet frem for regeringen får mere indflydelse på TVE1 (kilde: Personlig kommunikation med prof Juan Díez-Nicolás, Universidad Complutense de Madrid).

3. Kilde: Personlig kommunikation med prof Juan Díez-Nicolás, Universidad Complutense de Madrid, for valgene 1993 og 1996 se DíezNicolás \& Semetko (1999). Data for valgene 2000 og 2004 er endnu ikke offentliggjort.

4. Se blandt andre: Friedrichsen (1996); Krüger, Müller-Sachse \& ZapfSchramm (2005); Krüger \& Zapf-Schramm (1999, 2002); Maurer \& Kepplinger (2003); Schneider, Schönbach \& Semetko (1999); Schoenbach (1991); Schönbach \& Semetko (1994, 2000); Schulz (1996); Schulz, Berens \& Zeh (1998); Schulz \& Zeh (2003, 2005); Semetko (1996); Semetko \& Schoenbach (1994). 


\section{REFEREN CER}

Asp, Kent 1983: "The Struggle for the Agenda - Party Agenda, Media Agenda, and Voter Agenda in the 1979 Swedish Election Campaign", Communication Research 10(3): 333-55.

Asp, Kent 1988: „Politisk journalistisk - Studier i mediernas partiskhet och makt «, Nordicom Nytt 1988(4): 7-51.

Asp, Kent 2003: Medieval 2002 - Partiskheten och valutgången. JMG Arbetsrapport nr. 13. Gøteborg: Göteborgs Universitet, Institutionen för Journalistik och Masskommunikation.

Asp, Kent 2006: Rättvisa nyhetsmedier - Partiskheten under 2006 års medievalrörelse. JMG Arbetsrapport nr. 42. Gøteborg: Göteborgs Universitet, Institutionen för Journalistik och Masskommunikation.

Blumler, Jay G., Michael Gurevitch \& T. J. Nossiter 1995: “Struggles for meaningful election communication: television journalism at the BBC, 1992" s. 65-84 i Ivor Crewe \& Brian Gosschalk: Political communications: the general election campaign of 1992. Cambridge: Cambridge University Press.

Bro, Peter, Rasmus Jønsson, Søren Schultz Jørgensen \& Poul Anders Pedersen 2005: Mediernes Valgkamp - Et forsknings- og formidlingsprojekt om folketingsvalget $i$ 2005. Modinet - Center for Media and Democracy in the Network Society.

CSA 2000: Annexe 1-9. Paris: Conseil supérieur de l'audiovisuel. http://www.csa.fr/upload/dossier/pluralisme annexes septo6.pdf [07.12.2006].

CSA 2006: Guide d'application de la recommandation relative à la campagne en vue de l'élection présidentielle de 2007. Paris: Conseil supérieur de l'audiovisuel. http://www.csa.fr/upload/dossier/reco presi dentielle guide.doc [07.12.2006].

Díez-Nicolás, Juan \& Holli Semetko 1997: "For Whom the Bell Tolls: Competition for Audiences in Spain's Election Campaigns”. Paper presented at the annual conference of APSA, Washington 28.08.01.09.1999.

Díez-Nicolás, Juan \& Holli Semetko 1999: “Los programas de noticias de television y las campañas electorales de 1993 y 1996: Propiedad, contenido e influencia”, s. 151-201 i Alejandro Muñoz Alonso \& Juan Ignacio Rospir: Democracia mediática y campañas electorales. Barcelona: Ariel Communicación.

Entman, Robert M. 1989: Democracy without Citizens - Media and the 
Decay of American Politics. Oxford: Oxford University Press.

Esser, Frank \& Paul D’Angelo 2006: "Framing the Press and Publicity Process in U.S., British, and German General Election Campaigns”. Press/Politics 11(3): 44-66.

Esser, Frank 2002: „Transnationale Journalismusforschung“ s. 319-44 i Andreas Hepp \& Martin Löffelholz (red.): Grundlagentexte zur transkulturellen Kommunikation. Konstanz: UVKVerlagsgesellschaft.

Friedrichsen, Mike 1996: „Im Zweifel für die Angeklagten. Zur Wahrnehmung und Akzeptanz von Parteien im Superwahljahr 1994“, s. 45-79 i Christina Holtz-Bacha \& Lynda Lee Kaid: Wahlen und Wahlkampf in den Medien - Untersuchungen aus dem Wahljahr 1994. Opladen: Westdeutscher Verlag.

Gerstlé, Jacques 1991: “Election Communication in France”, s. 3-23 i Frederick Fletcher (red.): Media, Elections and Democracy. Toronto: Dundurn Press.

Gunter, Barrie 1997: Measuring Bias on Television. Luton: University of Luton Press.

Gurevitch, Michael \& Jay Blumler 1993: "Longitudinal Analysis of an Election Communication System: Newsroom Observation at the BBC 1966-1992". Österreichische Zeitschrift für Politikwissenschaft vol. 22(4): 427-44.

Harrison, Martin 1997: "Politics on the Air", s. 133-155 i David Butler \& Dennis Kavanagh: The British General Election of 1997. Houndmills: Palgrave Macmillan.

Harrison, Martin 2002: "Politics on the Air", i David Butler \& Dennis Kavanagh: The British General Election of 2001, s. 132-55. New York: Palgrave.

Hill, Irène 2004: "The Television Campaigns for the French Elections of 2002", s. 83-116 i John Gaffney (red.): The French Presidential and Legislative Elections of 2002. Hants (UK), Ashgate Publishing.

Hjarvard, Stig 1997: „Nyheder i billedet“, s. 149-63 i Klaus Bruhn Jensen: Dansk Mediehistorie - Bind 3 1960-1995. København: Samlerens Forlag.

Hjarvard, Stig 2006: „Tv-nyheder“, s. 105-44 i Stig Hjarvard (red.): Dansk tv's historie. København: Samfundslitteratur.

Hjarvard, Stig, Nete Nørgaard Kristensen \& Mark Ørsten 2004: Mediernes dakning af invasionen af Irak 2003. Working Paper no. 13. Modinet Center for Media and Democracy in the Network Society. 
Hofstetter, C. Richard 1976: Bias in the News - Network Television Coverage of the 1972 Election Campaign. Columbus: Ohio State University Press.

Hofstetter, C. Richard 1978: "News Bias in the 1972 Campaign: A CrossMedia Comparison”. Journalism Monographs vol. 58.

Hopmann, David Nicolas 2009: Politically Biased Coverage of National Election Campaigns? Studies on Danish Television News. Ph.-D. dissertation, Faculty of Social Sciences, University of Southern Denmark.

Jakobsen, Erhard 1977: „Meningsterroren i Danmarks Radio må standses“, Aktive Lyttere og Seere Nyt 1977(1): 5-6, 11-13.

Kamil, Carolina 2007: „Partisk nyhedsdækning? Mod en forståelse og måling af upartiskhed“, s. 111-29 i Martin Carstensen, Flemming Svith \& Per Mouritsen: DR og TV2 - i folkets tjeneste? Århus: Ajour.

Krüger, Udo Michael \& Thomas Zapf-Schramm 1999: „Fernsehwahlkampf 1998 in Nachrichten und politischen Informationssendungen“, Media Perspektiven 1999(5): 222-36.

Krüger, Udo Michael \& Thomas Zapf-Schramm 2002: „Wahlberichterstattung im öffentlich-rechtlichen und privaten Fernsehen“, Media Perspektiven 2002(12): 610-22.

Krüger, Udo Michael, Karl Müller-Sachse \& Thomas Zapf-Schramm 2005: „Thematisierung der Bundestagswahl 2005 im öffentlichrechtlichen und privaten Fernsehen“, Media Perspektiven 2005(12): 598-612.

Kuhn, Raymond 2004: "The Media and the Elections", s. 83-116 i John Gaffney (red.): The French Presidential and Legislative Elections of 2002. Hants (UK): Ashgate Publishing.

Kuklinski, James \& Lee Sigelman 1992: "When Objectivity Is Not Objective: Network Television News Coverage of U.S. Senators and the 'Paradox of Objectivity'”, Journal of Politics 54(3): 810-33.

Lund, Erik 1975: „Valgudsendelser i radio og TV 1924-1974/75“. Pressens årbog 1975. København: Dansk pressehistorisk Selskab.

Maurer, Marcus \& Hans Mathias Kepplinger 2003: „Warum die Macht der Fernsehbilder wächst - Verbale und visuelle Informationen in den Fernsehnachrichten vor den Bundestagswahlen 1998 und 2002“, s. 82-97 i Christina Holtz-Bacha (red.): Die Massenmedien im Wahlkampf-Die Bundestagswahl 2002. Wiesbaden:WestdeutscherVerlag. McQuail, Dennis 1992: Media Performance - Mass Communication and the Public Interest, London, Newbury Park, New Delhi: Sage. 
Norris, Pippa, John Curtice, David Sanders, Margaret Scammel \& Holli Semetko 1999: On Message - Communicating the Campaign. London: Sage Publications.

Patterson, Thomas \& Wolfgang Donsbach 1996: "News Decisions: Journalists as Partisan Actors”. Political Communication 13: 455-68.

Petersson, Olaf, Monika Djerf-Pierre, Sören Holmberg, Jesper Strömbäck, Lennart Weibull 2006: Report from the Democratic Audit of Sweden 2006 - Media and Elections in Sweden. Stockholm: SNS Förlag.

Scammel, Margaret \& Holli Semetko 1995: "Political Advertising on Television: The British Experience”, s. 19-43 i Lynda Lee Kaid \& Christina Holtz-Bacha: Political Advertising in Western Democracies - Parties \& Candidates on Television. Thousand Oaks, London, New Delhi: Sage.

Schiffer, Adam 2006: "Assesing Partisan Bias in Political News: The Case(s) of Local Senate Election Coverage”. Political Communication 23:23-39.

Schneider, Melanie, Klaus Schönbach \& Holli Semetko 1999: „Kanzlerkandidaten in den Fernsehnachrichten und in der Wählermeinung Befunde zum Bundestagswahlkampf 1998 und früheren Wahlkämpfen“, Media Perspektiven 1999(5): 262-69.

Schoenbach, Klaus 1991: "Mass Media and Election Campaigns in Germany”, s. 63-86 i Frederick Fletcher (red.): Media, Elections and Democracy. Toronto: Dundurn Press.

Schoenbach, Klaus, Jan de Ridder \& Edmund Lauf 2001: "Politicians on TV: Getting attention in Dutch and German election campaigns", European Journal of Political Research 39: 519-31.

Schönbach, Klaus \& Holli Semetko 1994: „Medienberichterstattung und Parteienwerbung im Bundestagswahlkampf 1990“, Media Perspektiven 1994(7): 328-40.

Schönbach, Klaus \& Holli Semetko 1995: ,Journalistische 'Professionalität' versus Chancengleichheit von Regierung und Opposition: Ein Dilemma der aktuellen Berichterstattung im Wahlkampf“, s. 49-64 i Kl. Armingeon \& R. Blum (red.): Das öffentliche Theater: Politik und Medien in der Demokratie. Bern, Stuttgart, Wien: Paul Haupt.

Schönbach, Klaus \& Holli Semetko 1996: „Wahlkommunikation, Journalisten und Wähler: Fünf Thesen zum Bundestagswahlkampf 1990 mit einem internationalen Vergleich und einem ersten Blick auf 1994“, s. 153-64 i H. Oberreuter (red.): Parteiensystem am Wendepunkt? Wahlen in der Fernsehdemokratie. München: Olzog Verlag. 
Schönbach, Klaus \& Holli Semetko 2000: „Gnadenlos professionell’: Journalisten und die aktuelle Medienberichterstattung in Bundestagswahlkämpfen 1976-1998“, s. 69-89 i Hans Bohrmann, Otfried Jarren, Gabriele Melischek \& Josef Seethaler: Wahlen und Politikvermittlung durch Massenmedien. Wiesbaden: Westdeutscher Verlag.

Schulz, Winfried \& Reimar Zeh 2003: „Kanzler und Kanzlerkandidat in den Fernsehnachrichten“, s. 57-81 i Christina Holtz-Bacha (red.): Die Massenmedien im Wahlkampf - Die Bundestagswahl 2002. Wiesbaden: Westdeutscher Verlag.

Schulz, Winfried \& Reimar Zeh 2005: "The changing election coverage of German television. A content analysis: 1990-2002”. Communications 30: 385-407.

Schulz, Winfried 1996: "Resonance Effects in Television News - A Study of the Success of the Chancellor Candidates' Strategies during the 1990 German Bundestag Elections", European Journal of Communication 11(1): 33-55.

Schulz, Winfried, Harald Berens \& Reimar Zeh 1998: „Das Fernsehen als Instrument und Akteur im Wahlkampf - Analyse der Berichterstattung von ARD, ZDF, RTL und SAT1 über die Spitzenkandidaten bei der Bundestagswahl 1994“, Rundfunk und Fernsehen 46(1): 58-79.

Seaton, Jean \& Pimlott, Ben 1983: “The Media in British Politics”, s. 133-53 i Jean Seaton \& Ben Pimlott: The Media in British Politics. Aldershot: Avebury.

Semetko, Holli \& Klaus Schoenbach 1994: Germany's 'Unity Election' - Voters and the Media. Cresskill (USA): Hampton Press Inc.

Semetko, Holli \& María José Canel 1997: "Agenda-Senders versus Agenda-Setters: Television in Spain's 1996 Election Campaign”, Political Communication 14:459-79.

Semetko, Holli 1991: "Broadcasting and Election Communication in Britain”, s. 25-62 i Frederick Fletcher (red.): Media, Elections and Democracy. Toronto: Dundurn Press.

Semetko, Holli 1996: "Political Balance on Television - Campaigns in the United States, Britain, and Germany", Press/Politics 1(1): 51-71.

Semetko, Holli 1996a: “The Media”, s. 254-79 i Lawrence LeDuc, Richard Niemi \& Pippa Norris: Comparing Democracies - Elections and Voting in Global Perspective. Thousand Oaks, New Delhi, London: Sage Publications.

Semetko, Holli 2003: "Political Bias in the Media”, s. 517-25 i D. Johnston 
(red.): Encyclopedia of International Media and Communications Vol. 3. Amsterdam, Boston, London: Academic Press.

Shoemaker, Pamela \& Stephen Reese 1996: Mediating the Message-Theories of Influences on Mass Media Content. White Plains (NY): Longman Publishers.

Smith, Anthony 1981: "Mass Communications”, pp. 173-95 i David Butler, Howard Penniman \& Austin Ranney: Democracy at the Polls. London: American Enterprise Institute for Public Policy Research.

Starkey, Guy 2007: Balance and Bias in Journalism - Representation, Regulation and Democracy. Houndsmills (UK): Palgrave Macmillan.

Weiß, Hans-Jürgen 1982: „Die Wahlkampfberichterstattung und -kommentierung von Fernsehen und Tagespresse zum Bundestagswahlkampf 1980“, Media Perspektiven 1982(4): 263-75. 


\section{English Abstracts}

\section{Public service and political balance: A typology}

\section{DAVID NICOLAS HOPMANN}

In an effort to understand and categorize media bias and balance in broadcasting journalism, this literature review proposes a new typology of different types of political balance in the broadcasting media: a typology that is not only based on an examination of media content, but also an examination of antecedents. That is, media output should be analyzed as a function of input processes. A new typology will be presented covering concepts such as media bias and media balance. Hereby, a framework for classifying media content is outlined helping us to compare cases across media outlets and countries. Throughout the article, four empirical examples will be discussed. Focus is on West European public service media outlets and their coverage of election campaigns. 